\title{
The Efforts of the Jordanian Civil Defense Director Major General Mustafa Al-Bzeaiha in the Development, Modernization and Administrative Reform of the Civil Defense Apparatus in Jordan (Descriptive Study)
}

\author{
Dr.Aref.Mohammed Mufleh AL.sarheed \\ Part-taim lecturer at Jordanian universities, Amman - Jordan
}

\begin{abstract}
Summary The aim of this study is to identify the efforts of the Jordanian Civil Defense Manager in the development, modernization and administrative reform of the Jordanian civil defense system in all aspects, at the level of laws, regulations and legislations, training human resources, holding professional courses, providing incentives, grants and assistance, Civil defense and local communities in Jordan, and to develop coordination and cooperation with local, Arab, regional and international organizations in the conclusion of conventions, courses and conferences in the field of civil protection, through the study of studies, reports, publications and books issued by the Jordanian Civil Defense, the study and analysis of achievements and the study of strategic plans, and the researcher reached the following main results achieved: 15 new civil defense centers were developed to reach (200) 20), a new ambulance service, the introduction of 13 rapid rescue vehicles, the introduction of an M126 aircraft, the increase in the number of UAVs, the modernization of the operations and control wing, the introduction of the command and control bus (2), the establishment of an integrated center For diving in the Dead Sea area, a special ambulance is attached to its cadres 84 medical personnel and drivers distributed over 14 security stations, the development of the Language Center, the Civil Defense Court, the Medical Center, the General Directorate of Civil Defense, the Electric and Research Vehicles Laboratory, the Human Resources Department, the Quality System and the Civil Defense Press. The development of the website, the development of the Prince Hussein Academy for Civil Protection, and the development of new specialties, cooperation with the Chinese, French, and Japanese sides, Italian, Swiss, German.
\end{abstract}

Keyword:Civil Defense, development, Civil Protection, achievements.

DOI: $10.7176 /$ RHSS/9-4-06

\section{Introduction:}

The civil defense work in the Hashemite Kingdom of Jordan dates back to the era of the Principality, where its work was carried out at the time by a number of civilian teams with limited number of tasks and working within the municipal staff. In 1948 and beyond, as a result of the events and the instability of the region, there was a need to find a body to protect civilians from the scourge of war. According to Article 18 of the Defense Law No. 2 of 1939, (3) for the year 1953.1 This Defense Order empowers the Minister of Defense to establish a Civil Defense Commission in the Hashemite Kingdom of Jordan in order to implement the objectives of the Civil Defense and to establish the necessary provisions for the implementation of these objectives: Assistance to parents affected by Ga Data and to guide them how to avoid damage. In 1954, the Minister of Defense issued the Defense Order No. (1) of 1954 (1), which included the formation of civil defense committees in the capital, Alawiya, In the wake of the tripartite aggression against Egypt in 1956, and based on the belief of His Majesty the late King Hussein Bin Talal, may Allah be pleased with him, that the most precious thing we have in this steadfast country, A civil defense system and accordingly the Civil Defense Law No. (12) of 1959 (3) was issued The civil defense remained part of the organization of public security until it was separated from it in administrative terms in 1970. In 1978, the Civil Defense Department separated from the Public Security Directorate financially and became its own budget. (Civil defense site). In keeping with the developments in the Hashemite Kingdom of Jordan in the 1990s, including development and prosperity, the Civil Defense Law No. (18) of 19995 replaced the Civil Defense Law No. 12 of 1959. The Directorate General of Civil Defense, after the issuance of the Civil Defense Law No. (18) of 1999, made a quantum leap in various fields of work. It was a huge leap forward in deliberate steps derived from the connected care supervised by this noble human body and received by the triumphant Hashemite leadership.

The horizontal expansion was achieved through the opening of new civil defense centers and the introduction of advanced mechanisms, equipment and devices of high technical and advanced technology. The systems, laws and plans were updated and developed along with a wide range Updates in the unwieldy nature science and techniques of civil defense. (Civil Defense website website .(The Jordanian Civil Defense seeks to achieve its objectives through the vision: pioneers in civil protection and a model of comprehensive civil defense. Mission: Humanity, belonging, creativity, teamwork, sacrifice, honesty. The organizational structure of the civil defense apparatus consist. 
The tasks and tasks of the departments are defined by objectives, mission and vision, short-term, mediumterm and long-term strategic plans. For example, the strategic objective of the Department of Information and Preventive Education is to strengthen the community culture of preventive safety by spreading a culture of public safety to all segments of society by raising awareness of the concept of comprehensive civil defense, which means that every citizen acts as a civil defense in his or her position.

Through the positive partnership between the Department of Information and the various media institutions in delivering their preventive educational message .The Disaster Management Unit undertakes the following duties: Preparing studies and research on natural and man-made disasters and documenting related information, identifying prevention methods and working methods in coordination with the Department of Operations to cope with the expected disasters in Jordan in cooperation with the concerned authorities inside and outside Jordan.

And to inform the Supreme Council of Civil Defense of the manner and developments of disaster response and to put forward the important topics on its agenda at its meetings. And to coordinate and cooperate permanently with all official and civil authorities locally and internationally on all aspects of disaster management, response and elimination. And conducting pre-emptive exercises to deal with disasters in coordination with the Department of Operations with the participation of the Civil Defense Committees in the administrative formations. And submit recommendations to the Director General of the placement to the President of the Supreme Council of Civil Defense on the fulfillment of all the requirements of disaster response within the powers conferred upon His Excellency.

Technical supervision of the readiness of hazardous materials teams and the search and rescue team . Participate in the preparation of national plans for disaster management and emergencies. Coordinating with the Supreme Council of Civil Defense and its committees to choose the collective accommodation sites and the mechanism of processing and follow up their performance. Participate with the Training Department in the development of training programs for emergency teams on the work of dealing with disasters.

Coordinate with the Crisis Management Center of the Armed Forces on joint plans to address emergency situations during disasters and define roles and responsibilities assigned to each. Gathering and disseminating disaster information among official and non-official institutions in cooperation with the Department of Public Relations in the General Directorate of Civil Defense.

Preparation and follow-up of international and bilateral agreements on civil protection and in the field of disaster cooperation and activating these agreements. The vision is to achieve the concept of comprehensive civil defense within a clear strategy that ensures safety for the citizens of the country and its residents wherever they are in the Kingdom.

The message is to contribute to preserving the lives and property of the citizens and the country's capabilities from various risks by raising their preventive awareness and enhancing the application of safety methods. To the general public in the community through the use of all audio, visual and visual media. Thus, each constituency is based on a set of tasks to achieve the overall goals of the civil defense .The procedures, duties and duties of the Civil Defense have been determined through legislation, laws, regulations, regulations and instructions.

These laws regulate the work processes, plans, short-, medium- and long-term strategies to achieve comprehensive civil defense, which is supervised by Major General Mustafa Al-bazaya . The law deals with a set of articles and instructions which is the Civil Defense Law No. (18) of 1999, the most important of which is: In Article 3A, a council called the Supreme Council for Civil Defense, headed by a member of the Civil Defense Director, Secretary General of the Youth Council, Secretary General of the Jordanian Hashemite Charity Organization, Assistant to the Chief of Staff, Director of Public Security, Assistant to Director of General Intelligence and Gendarmerie, Director of Amman City, President of Jordan Red Crescent Society, President of Federation of Chambers of Commerce With the following: The General Secretariat of the Civil Defense to deal with emergencies and the consequences thereof, and approve the general plans to take the necessary measures to deal with emergency situations, disasters and determine the duties of each official or civil authority, and to approve the plans necessary to confront chemical, radiation and bacterial pollution and toxic gases to ensure prevention and protection, And the establishment of voluntary teams of civilians between 18 and 50 years of age to support the work of the civil defense.

Defining the duties and tasks of the defense committees formed under the provisions of this law in the governorates, and other duties that aim at achieving the supreme royal vision in the field of civil protection (Civil Defense Law, 1999). (In each governorate, a committee called the Local Civil Defense Committee shall be established and the Council may form a committee for civil defense in each district or district headed by the administrative governor.

In case of emergency and disaster, the council may decide the following: Civil Defense Committees are available to official and civil authorities in the Kingdom, including fire engines, their equipment and all their supplies and personnel at the disposal of the Minister. The General Directorate of Civil Defense shall be composed of the Director, a number of officers, personnel and employees as required. 
The Director General shall be appointed by a decision of the Council of Ministers upon the recommendation of the Minister. The decision shall be accompanied by the supreme Royal Decree. The Minister and shall be responsible to him for the proper functioning of it.

Article 13: The Directorate General shall undertake the following tasks and duties: To carry out fire and rescue operations and the resulting cases of ambulance, to prepare qualified personnel for such operations and the quality of the citizens and to train them and to provide the necessary mechanisms, equipment and means of communication; To detect the explosives, to identify their areas of existence and to mark them, and to call on the public security forces to close the area and the competent organs of the armed forces To participate in the detection of any chemical or radiation leakage in cooperation with the competent authorities to process and avoid its effects, recommending the establishment of fuel stations and liquefied gas distribution and storage depots, in accordance with the conditions of protection and self-protection prescribed, study of multi-storey buildings and buildings with commercial uses Industrial and tourism, identifying preventive measures and means of selfprotection for the purpose of granting the manufacture, storage and sale of explosives, fireworks, chemicals, hazardous materials, etc., training volunteer teams on the work of civil defense Public and private sectors throughout the Kingdom to support the civil defense, to ensure the availability of protection requirements, means of self-protection, and the means of warning and firefighting of commercial shops and industrial professions, representation of the Kingdom in international and regional organizations and conferences of civil defense and civil protection, implementation of any other duties related to the work of civil defense The Minister or the Director-General of the Civil Defense considers it necessary (Civil Defense Law, 1999)

This study aims to identify the efforts of the Civil Defense Manager in modernization and development. of the Civil Defense.

Study problem and questions This study attempts to answer the following questions 1-What are the objectives, mission, values and duties of the Jordanian Civil Defense Organization

2.What aspects of development, modernization and administrative reform carried out by the Civil Defense Director of the Civil Defense Department?

3-What aspects of development, modernization and reform in the area of social responsibility towards employees? 4-What aspects of development, modernization and reform in the area of social responsibility towards local communities in Jordan?

The objectives of the study are summarized as follows:

1- dentify the vision, mission, objectives, duties and values of the civil defense apparatus..

2- the -aspects of administrative reform, development and modernization of civil defense system in the field of civil protection and social responsibility.

3-Defining the role of the defense apparatus in cooperation and coordination with local, Arab, regional and international organizations in the field of conferences, programs, research and studies in civil protection and disasters..

4-Defining the aspects of achievements and strategies in the governmental departments and institutions development, modernization and reform, and transferring the civil defense experience to all the organs of the Jordanian state and applying these.

5-Contribute to the definition of Jordanian society and those interested in the field of civil protection aspects of creativity and development efforts of civil defense in civil protection..

\section{The importance of studying:}

The Jordanian Civil Defense Department under Major General Mustafa Al-Bazayea witnessed huge leaps in many areas in terms of strategic planning, legislation, incentives, grants, assistance and training programs, the opening of new directorates, the massive expansion in the field of civil protection sciences, preventive education and occupational safety programs, And the development of the Academy of Prince Hussein bin Abdullah Civil Protection, and the College of Civil Defense, and provide them with the scientific and human expertise and competencies, it was necessary to stand on these achievements and aspects of development and modernization, Loomed for the transfer of the civil defense experience to the Jordanian state civil and military institutions, in particular the Civil Defense received the King Abdullah Award for Excellence in Government Performance.

\section{Terminology of study:}

Jordanian Civil Defense: It is a Jordanian public government organ, affiliated to the Ministry of the Interior. Its main function is to protect and save lives and private and public property, whether for citizens or residents of Jordan. The functions of the Jordanian Civil Defense are to intervene to provide assistance and assistance to people in the event of accidents and disasters, and to protect the property from dangers by fortifying the buildings in order to avoid accidents such as fire, drowning, traffic accidents, landslides, poisoning and air pollution .and reform Development, modernization and reform Development : are efforts aimed at achieving fundamental changes in the public administration system through comprehensive reform processes or at least 
through measures to improve one or more of its key components at the administrative and regulatory structures, manpower, legislation, laws, regulations and instructions, , To create significant positive development to improve performance towards greater efficiency and effectiveness Director of Civil Director of Civil Defense Director of Civil Defense: The Director-General shall be appointed by a decision of the Council of Ministers upon the recommendation of the Minister. The decision shall be accompanied by the supreme Royal will. The Director General shall manage all the affairs of the Directorate General and its organization.

\section{Theoretical framework and previous studies;}

During the reign of the Emirate, the municipalities were responsible for civil defense and were carried out by civilian groups with simple equipment to carry out firefighting operations only. In 1948, there were voluntary teams to support the civilian groups in their work, and the municipality of Amman trained them on rescue and rescue work. In the same year, the defense system No. (7) of 1948 (the requirements against air raids) was issued and the center of the capital was provided with a fire engine, The Center was under the supervision of the General Security and pursuant to the Defense Order No. (3) of 1953, issued by the Prime Minister A. The Minister of Defense, "Civil Defense Organization" in the Kingdom, and its objectives were defined as follows: Preservation of life by means of prevention methods and preservation of property, And to provide assistance to the affected families $\mathrm{N}$ ) as a result of the raids and instructing them on how to avoid harm (conservative national education .(In the following year, civil defense committees were established in the capital and centers of brigades, districts and districts to assume the functions of civil defense.

The Interim Civil Defense Law No. (35) of 1956 established the duties and actions of the civil defense, and the creation of the civil defense department affiliated with the Ministry of Interior. The Law of Defense No. 12 of 1959 was adopted to replace the aforementioned law. The law was amended in 1962, 1966 and 1970 to grant civil defense the right to supervise the storage and distribution of gas cylinders., And The Civil Defense Department was subordinate to the Directorate of Public Security and became an independent Directorate linked to the Minister of the Interior in 1970, but remained financially linked to the Directorate of Public Security until In 1978, when it had its own budget (province .(The Civil Defense Directorate is responsible for extinguishing forest fires and transporting dangerous chemical substances on roads, in addition to the tasks mentioned above. The Civil Defense Law No. 18 of 1999 was issued to respond to the needs of Jordan, To the requirements of the Jordanian reality, and to develop plans to meet the dangers in a scientific manner, and coordinate the efforts of the institutions of the State concerned with civil defense.

The new law defined the duties of the Directorate of Civil Defense and defined its duties . The Civil Defense Department promotes the concept of civil protection in a comprehensive manner by carrying out firefighting, rescue and ambulance operations, preparing trained and qualified personnel for these operations, educating citizens and training them, securing mechanisms and equipment, communication means, conducting civil defense studies, And rapid intervention for disasters. Providing protection and assistance to people in the face of disasters and risks is an important task for the State, its public facilities, which are the backbone of public utilities, Civil Protection, which is one of the public utilities in the State. Civil protection works to protect life, property and the environment. It aims at educating individuals about the functions of the national civil protection agencies.

The most important functions of civil protection are the study of security rules and procedures applied in the field of civil protection against all dangers of fire and panic And prevent them from various types of industrial and public institutions, and monitor the implementation of this. The prevention of industrial and technological major threats.

The fight against forest fires and agricultural crops. Protection of beaches and recreation areas. Accidents (fires, explosions, floods, etc.), and household accidents of all kinds, road and rail accidents, and information and awareness of various types of accidents. And the implementation and coordination of emergency plans in the event of major disasters and so on.

Where all civil protection agencies in all countries seek to fulfill these duties, and the Jordanian civil defense part of these devices to protect lives and property, where the strategic plan of civil defense 2017/2019 to focus on aspects Development and administrative reform and contribute to national development within the vision of 2025 The strategic plan aims to achieve the highest degree of coordination and integration between the Jordanian civil defense and all state institutions and agencies in achieving national and sectoral goals, including: The Civil Defense Service contributes to the provision of services Integrated health and related.

The quality of its individual axis and respond to the increasing needs, efficient management of crises, disasters and risks, the development and rehabilitation of human resources and management and distribution of justice, and the development and provision of emergency services and rescue efficiently (Strategic Plan 2017/2019. (There is no doubt that the overall development and reform efforts of the Jordanian civil defense system have undergone a qualitative shift in all facilities and at all levels, human resources, rehabilitation and training, incentives and grants, social responsibility programs and the expansion of centers throughout the 
Kingdom. In which the services were developed and the citizen touched on aspects of development and comprehensive modernization. Al-Basha affirmed the continuous development and modernization of the system with the direct support of His Majesty King Abdullah II. The number of defense sites reached 200, And the training of the human resources. The ambulance was developed from the first to the specialized medical ambulance, the search and rescue team was formed, the training of 300,000 volunteers was carried out on the civil defense work, the M12 was introduced to service the apparatus, the fire system was installed in Al-Aqsa Mosque, Civil Award for King Abdullah Award for Excellence in Government Performance and Transparency in Quality of Services at the National Level, which is offered to citizens and residents (Jordan News Agency, 2018).

The Jordanian civil defense director said that since the beginning of 2018, the civil defense has dealt with 264 thousand accidents throughout the Kingdom. The incidents include ambulance, fire and rescue, protection of property valued at 273 million dinars as a result of rapid intervention. Second to treat an accident or transfer a satisfactory condition (Al-Ghad Journal of Jordan, 2018).

The Civil Defense Director stresses the importance of training, qualifying civil defense cadres and the importance of training in honing the skills and raising their competencies to enable them to perform their duties professionally. The training process plays an important role in developing the civil defense salaries, 2018 .(The Director General of the Civil Defense, Major General Mustafa Al-Bazaiha, said that the Directorate seeks to promote a culture of excellence, good governance, sustainable development and improvement in accordance with best practices and the activation of its role and purpose in protecting the lives and property, and protecting the security and safety of the citizen and the homeland, including the public interest.

On the continuity of the strategic planning approach through the preparation and implementation of strategic plans, which is the proper approach in the management and organization of efforts by the Jordanian Civil Defense to keep abreast of developments and meet challenges in line with national priorities and And the quality of the procedures and systems that consolidate the system of collective and participatory work, and the development of institutional performance and investment of human and material resources.

He pointed out that the Directorate adopts the approach and principles of institutional work and came to realize the orientations and aspirations of the country's highest interest minister Of the Jordanian Armed Forces His Majesty King Abdullah II Bin Al-Haysin towards Jordan has a place on the map of the world and has a role in contributing to human civilization, we hope that all efforts of all concerned and partners to join together Translate these plans and directions into reality to promote development and success at the local, regional and global levels under the Hashemite leadership (Strategic Plan, 2017/2019), .(The General Directorate of Civil Defense seeks to work through the comprehensive development and modernization of the system to contribute to the achievement of the national objectives set out in the executive program of the first phase or the Jordan Document (2025), including achieving sustainable growth rates to ensure a standard of living, (The strategic plan 2017-2019). The role and contribution of civil defense in this regard is through the provision of integrated, quality, individual-centered health services that respond to increased needs, efficient management of crises, disasters and risks, Development and rehabilitation of human resources and management and distribution of justice, and develop partnership and cooperation with several departments and institutions, including: the Ministry of Health, the Supreme Council for Population.

Hospital University of Jordan, Royal Medical Services, Jordan Medical Council, National Center for Security and Crisis Management, Jordan Television, Ministry of Interior, Amman Municipality, Public Security, Gendarmerie, Ministry of Public Works, Ministry of Finance and Ministry of Planning . The Civil Defense works to achieve the vision of Jordan (2025) through the continuous development and improvement of coverage coverage in the Kingdom, reducing the rate of response to accidents, training for various community leaders, the readiness and efficiency of operation and equipment mechanisms, and the presence of qualified trained and qualified cadres capable of training teams and supervising The readiness and efficiency of manpower, the readiness of emergency teams and the readiness of early warning. The strengths of the civil defense system are: the existence of strategic plans, detailed operational and operational plans, And the implementation of civil defense for many projects concerned, capacity building and the development of efficiency, and increase the geographical spread of civil defense sites, and the absence of a competitor to the civil defense, and the existence of clear instructions for the training of volunteer teams, and supervision in coordination with other parties (Strategic Plan for Civil Defense, 2017-2019).

\section{Previous studies;}

Halwani(1994), The study aimed to review the concept of administrative change and its image and analyze the process of change and explain the reasons and means of resistance by some members of the organization. Among the most prominent results: the lack of commitment of administrative organizations to change planned and thoughtful, And the lack of compatibility between the goals of change and the objectives and trends of individuals, and the recommendations of the study: must be committed to change planned and thoughtful so that 
the change towards the target tagged.

Abd ALbariDurra (1990), The study aimed at clarifying the role played by the administrative development units in the administrative reform, giving a clear picture of the employees in these units and identifying their views in the administrative development units in the subject of needs. The most important results of the study: The managers of administrative development units in the state apparatus are not qualified to assume the responsibilities and burdens placed on these units, and therefore can not achieve the goals, where $20 \%$ of them hold a qualification without a bachelor, and $31 \%$ of their experience in this area What For one year .oaattabr skills training, behavioral and administrative sciences of the most important types of training that ensures raising achievement rates, the study recommended the need to establish the conditions and the basis for the selection of workers in these Alouhddat.

Al-Awamla, Nael (1992), The study aims to identify the nature of the organizational change in the public administration organs in Jordan and analyze its dynamics. The results of the study: The general agreement of the respondents on the benefits and the feasibility of organizational change was one of the most prominent Problems of organizational change The weakness of preparation and study and the resistance of workers to change, the study recommended the need to adopt a specific policy in the field of organizational change in the organs of public administration in Jordan, providing appropriate training for employees in these units.

Al-Henaiti's study in 1994, Director's Attitudes toward Development and Administrative Reform in the Public Sector in Jordan, aimed at identifying managers' attitudes towards development and administrative reform in order to find suitable solutions for the development of government agencies. Which is the focus of managers in Jordan and the shortage of trained manpower.

ElBaradei, Laila (2000 )The study aims at reviewing the most important contemporary trends of administrative reform and controversy. This study examines the recent changes in management science, as well as the requirements of state institutions for internal reforms or comprehensive administrative development, and from the study of modern trends in administrative reform study. The most prominent results of the study: Influenced development in the field of public administration and administrative reform movements and programs in the evolution of economic and political theories around the world, the trend in the administrative reform movements is also towards the further application of the principles of good governance and rule of law $\mathrm{M}$, transparency and accountability.

Al-Qariuti, Muhammad and Al-Anzi, Awad (2004),The study aims to identify the administrative reality in the governmental sector and its achievements through the administrative and practical development plans and to strengthen the efforts towards the continuation of the study. The study recommends the following: To develop a clear national strategy for administrative development by specialists in the public administration and all the actors in the community.

The results of the study showed that the organization's adoption of clear strategies in the long term requires the organization to achieve high levels of efficiency. The study aims to identify and diagnose the most important administrative problems. The study recommended the following: Increase interest in research on the effects of administrative development other than demographic factors such as work on the stability of psychological workers and their steadfastness in service through appropriate material incentives.

Al-Nuaimi, Ahmad (1998), The study aims at identifying the need for administrative development units in the ministries of the State of Qatar, the problems faced by the administrative system in Qatar, and the problems facing the administrative system in Qatar. Results of the study: The process of administrative development depends on the managers' conviction of the objectives of development and their understanding, the process of administrative development is necessary for the development of the organization and progress, the process of administrative development suffers from the absence of strategy and plans.

The results of the study were as follows: The weakness of the training in the means of using technology is one of the main obstacles facing the application of technical development.

The results were: The reasons for the low performance of the administrative system are due to: low salaries, absence of an effective incentive system The lack of linkage of leadership to creativity, and the existence of functional inflation.

A study by Ambel and Sens Bagh, 1992, on creativity in human resources and development organizations in the United States. This study aimed to identify the factors that affect the creativity and development in organizations negatively or positively. The study results: the lack of adequate rewards, Regarding the selection and business reports to be completed.

abed alharabheh(2003),The Effect of Administrative Development on the Performance of the Audit Bureau The results of the study showed clear success for many of the objectives of the administrative development program at the Jordanian Audit Bureau.

Methodology: The researcher used the descriptive analytical method through the description, evaluation, monitoring, classification and analysis to identify the aspects of development, modernization and administrative reform in the civil defense system. The researcher relied on books, studies, articles, periodicals, research, reports 
and strategies, It is carried out by the director of various civil defense, which is written and written in the local press, the media and the Jordanian satellite stations.

Study tool: The researcher relied on the study tool to monitor, classify, analyze, tabulate and compare the answers to the study questions, collect and arrange the abstracts, and find results to answer the study questions.

Study Society: The study community consists of the Jordanian Civil Defense Organization. It is an internal study of the system to identify aspects of development from legislation, laws, development and comprehensive modernization.

\section{Discussion of the study results:}

First: the results of the study related to the answer to the first question, which states: What are the goals, mission, values and duties of the Jordanian Civil Defense? Monitoring, classification and analysis shows that the vision pursued by the Civil Defense is as follows: The vision: pioneers in civil protection, and a model of comprehensive civil defense. The message: Protecting and saving lives, and property with high readiness, to ensure the safety of the homeland and the citizen. Values: humanism, belonging, sacrifice, honesty, teamwork, creativity. When we talk about the duties of the General Directorate of Civil Defense, they have been defined in the Civil Defense Law No. (18) of 1999, which is summarized as follows:

-To carry out fire and rescue operations and the resulting ambulances, prepare qualified personnel for these operations, educate citizens and train them, and provide the necessary tools, equipment and means of communication, and prepare studies on the work of civil defense. Provide gas and disaster warning and control tools and tools. And check the security of public shelters and readiness for reception. Detection of explosives and identification of their areas of existence. And contribute to the detection of any chemical or radiation leakage, in cooperation with the competent authorities. And approval of the establishment of fuel stations, liquefied gas agencies and their warehouses. And the training of voluntary teams on the civil defense work, both public and private, throughout the Kingdom to support the civil defense. Representing the Kingdom in international and regional organizations and conferences for civil defense and civil protection. And to study the designs of commercial, industrial and tourist buildings and establishments, which the Greater Amman Municipality and other municipalities must refer to them to ensure that the requirements of the protection and other self-protection are protected from the fire, according to the prescribed specifications. .

Here, we see that the duties of the Directorate General of the Civil Defense are varied and varied to cover all aspects of civilian life. Therefore, the volume of work done by these cadrekers is dangerous and overwhelming. Here, the Director General of the Civil Defense, Al-Basha Mustafa Al-Bazaie, explains: "We in the Civil Defense Corps To be the loyal soldiers of our homeland and our long term, and we will work to provide the best services, to achieve the highest levels of safety and prevention of risks to our country as our supreme leader wanted, an oasis of security, security and stability that serves the citizens and distinguished guests and residents at home.

Second: The results of the study related to the answer to the second question: What are the aspects of development, modernization and administrative reform carried out by the Director of Civil Defense in the Civil Defense Department? The analysis, study and research revealed that the aspects of development, modernization and administrative reform carried out by the Director General, Major General Mustafa Al-Bazaeeh, Director of Civil Defense, are many and varied, such as the Directorate General of the Civil Defense in creating qualitative transfers, logistical and technical services, Human resources, laws and regulations, legislation and administrative system to keep abreast of the comprehensive renaissance witnessed by the Kingdom, and under the guidance of the Director General, Major General Mustafa Al-Bazaie, and with the support and collective effort of all the devices have been achieved in the era of Al-Basa Al-Bazaie (200), upgrading and upgrading (20) mechanism and fire tower (30) $\mathrm{m}$, and tower mechanisms, the introduction of 45 ambulances, 13 mechanism, the introduction of aircraft (m126) for service, modernization wing (2), classification of the international search and rescue team, the establishment of an integrated dive center in the Dead Sea area, 14 ambulances, 84 paramedics and drivers deployed in 14 security stations, In the presence of His Majesty the King / following the major daily incidents in a personal manner, the development of the Language Center of Petra The Civil Defense Court, 1/1/2018, the Medical Center of the General Directorate of Civil Defense, the Electrical and Research Vehicles Laboratory, the introduction of the leadership of the Occupations Group, the detention centers, the creation of a Civil Defense Directorate west of Irbid, The structure of the General Directorate of Civil Defense and the provision of financial savings estimated at 7 million dinars, and increase the number of manpower in the system, the development of the printing press and civil defense shop, to (123) visits to defense sites and identify the needVisits to defense sites, identification and treatment of needs and demands, increase Hajj and Umrah missions, 2019 reached 333 for Umrah, Hajj reached 80, increase incentives and allowances, create a unit for female soldiers, develop the website of the Directorate, Ghazala, the establishment of a civil defense center in the Blue Free Zone, and the civil defense volunteers project, to cooperate with the German, Italian, Swiss, French, Japanese and British sides to develop the Prince Hussein Academy and provide them with new 
specialties, qualified cadres, $(27,919)$, an increase of 4,152 people during the year and a half, completion of the construction of quality management systems in the Directorate General, raising 150 dinars for officers, 100 dinars for officers, raising the allowance for trained officers 40 dinars, and non-commissioned officers and individuals 40 dinars, Buildings in the field of search and rescue for the re-classification exercise of the search and rescue team 2018, the introduction of specialized courses with the armed forces, national defense courses: Taiyun, Chinese language course, the course of officers qualification, increase housing apartments, and finally received the King Abdullah Award for Excellence in Government Performance The Directorate General of Civil Defense receives the Center In the implementation of the requirements of the system of development of government services issued by the Prime Minister and the level of 2.94 of (3) within the fifth annual survey, which was attended by (71) Ministry and institutions and government service. Support recipients of the first positions as well as from the fourth to the tenth bridging to the Bachelor's degree Prince Al Hussein Bin Abdullah Academy for Civil Protection and 40\% discount for employees and sons of Civil Defense employees who wish to complete their university studies.

Third: The results of the study on the answer to the third question: What aspects of development, modernization and reform in the area of social responsibility towards its employees? The researcher, through the comprehensive review of the social responsibility aspects of civil defense personnel and through the guidance of the Pasha Mustafa Al-Bazaya, Director of Civil Defense, reached the following aspects of civil defense service manpower. These aspects: The concept of social responsibility lies in the commitment of the owners of institutions in sustainable development While improving the conditions of employees and their employees and their families as well as the community surrounding them socially, healthily and culturally, and providing humanitarian services to them. The Civil Defense Department picked up this vision and applied it to The social responsibility includes social, economic, charitable, religious, humanitarian and training aspects, including: visits and gifts for patients 1051, material assistance 749 , Blood donation 329, in-kind assistance, maintenance of houses 1, furnishing of furniture 3, Hajj and Umrah missions 282, religious lectures 3244, health education 433, drug awareness 441, smoking cessation 130, participation in 659 meals, Ramadan breakfasts 30, Students orbit Q 386, active activities for staff 176, recreation for employees (Sharm el-Sheikh Aqaba) 99, beneficiaries of housing housing 63 , beneficiaries of civil defense wedding halls 9 , beneficiaries of civil defense officers club 127, beneficiaries of food ration coupons 327, In Aqaba 151, Beneficiaries of the Good Parcels 372, Beneficiaries of the Transport Vehicles of the Dead 10, Accessories for Furnishings, Tablets and Other Tables 38, Beneficiaries Furniture Manufacturing 29, Beneficiaries of Furniture Transfers 73, Beneficiaries of Administrative Transfers 1788, Beneficiaries of Ambulances for Humanitarian Cases 230, Beneficiaries of Communications Offers 7412, Eng Staff Involvement in Civil Defense Magazine 30, incentive incentives 60, incentive incentives for the ideal employee 10, leaflets 81 , the senior management response in the directorates to the calls made by the civil servants in a manner that motivates and encourages employees to provide the best 24 , the liaison officer with Queen Alia International Airport facilitates the process Travel and reception of civil defense personnel (airport directorate) 56, Hajj and Umrah 252, number of movers 7961, establishment of specialized unit for women's affairs, dispatch of leaders in courses such as the national defense course of Taiyun, Chinese language courses, monthly meetings with all directorates to address problems and provide solutions $40 \%$ discount for employees and sons of civil defense personnel who wish to complete their university studies, increase the number of housing flats, offer scholarships to the first students in the Civil Defense College to complete their studies at Prince Hussein Civil Protection Academy from the first to the tenth to assess and motivate students. To workers in a way that promotes loyalty and loyalty to work, sponsoring national and religious ceremonies. There is no doubt that these creative aspects, which are carried out by the Civil Defense Authority and during the first half of 2017, constitute a real and creative will to activate social responsibility towards the employees of this apparatus. It covered social, health, educational, humanitarian, religious, training and housing aspects to serve and alleviate the suffering of workers. By the Civil Defense Department and under the leadership and patronage of Al-Basha Mustafa Al-Bazaie, to serve as a role model for implementation in all departments of the State to benefit from the experience of social responsibility and activate it towards employees to develop human resources and provide incentives, Develop and improve the performance of employees. Fourth: The results of the study on the answer to the fourth question: What aspects of development, modernization and reform in the area of social responsibility towards the local communities in Jordan? Through monitoring, classification, analysis and followup, the researcher shows that the aspects of social responsibility by the civil defense to the local communities in Jordan and through Follow-up, recommendations and instructions of the Director of Civil Defense, Major General Mustafa Al-Bazai'a, under his personal supervision due to the role of responsibility in helping people and alleviate their problems, was as follows: In implementation of the methodology of community responsibility, All its departments have a number of activities, programs and voluntary initiatives to achieve community development and environment, in addition to taking into consideration the needs and requirements of salaries in the following areas:

1-The social aspect: Providing breakfast for children of cancer patients in cooperation with the 60-person Silk 
Initiative in the Club of Civil Defense Officers. Gifts were distributed to the participating children. 2- Health side: opening of a medical center for civil defense salaries within the Directorate's campus, Support for Women's Affairs A group of female soldiers was honored in the commemoration of the Battle of Karama and Mother's Day. 4. The Environmental Side: Celebrating the Tree Day in the Central Civil Defense Reservoirs in Muwaqir, Voluntary initiative "cleanliness of the sea Including the cleaning of the beach of the park and in the depths of the water such as metal waste and glass cuttings, tree planting in the Directorate of Civil Defense Karak, 5 awareness and training: workshops on the work of D. workers in the children's villages SOS branch Erbed to raise awareness about safety And the experience of firefighting during the period from 14/52018 to 17/5/2018, the holding of training programs for people with special needs: the number of courses (2) and the number of beneficiaries (110), and also (20), and the number of beneficiaries (510) Participating in the national program of the Ministry of Education through awareness The principles of first aid and the principles of public safety The program targets the student age group between (15-17) where the number of participants (5000) students and (140) civil defense salaries, the launch of the game peace and Khartoum, training lectures for community women in charities In the Directorate of Civil Defense in Irbid, where 5 lectures were covered for them and the number of beneficiaries was (195) women, the joint meeting between security affairs and the administration of religious guidance and awareness to raise awareness of extremist thought and drugs. D In coordination with the Prince Ali bin Al Hussein Club for the Deaf and the Honorable Vice President of Mu'tah University for Academic Affairs of the Director of the Civil Defense of Karak, the Director of the Karak Civil Defense was honored for carrying out an imaginary exercise to save the injured in the event of disasters. This is the first exercise of its kind at the University of Mu'tah, where it includes plans for evacuation, rescue and rescue in a highly professional disaster. These community initiatives were carried out in the first half of 2018. Initiatives are ongoing and ongoing to serve local communities in Jordan.

Fifth: Recommendations of the study: The researcher finds through the study, research, monitoring and classification that the features and qualities of leadership and ambition, and the desire to accomplish, and work hard and continuous and continuous, and the development of creative ideas and development, are the leadership aspects and enjoyed by the Director of Civil Defense Major General Mustafa Bazaye, Has made the achievement, development and comprehensive modernization of the Jordanian civil defense system by providing support and support. The Director General of Civil Defense sought to achieve the following;

Provides employees with the opportunity to acquire knowledge, ideas, skills and continuous and continuous training to keep abreast of changes and developments, simplifying procedures, reducing administrative decentralization, facilitating the completion of transactions for citizens and auditors. Involve all levels of management and leadership in the formulation of goals, programs, strategic plans, and policies, work to involve decision-makers, seek cooperation and coordination with all workers in institutions and parents To coordinate with international, Arab, regional and national organizations to achieve the concept of civil protection. It works to reduce poverty and unemployment by recruiting in the civil defense system and from all the provinces and brigades of the Kingdom, which contributes to the development of higher education and community service. Through the Prince Hussein Academy for Civil Protection, works to activate social responsibility by providing support and support to civil defense personnel and local communities in Jordan, working on the development of equipment, mechanisms and manpower for the The study is the first study in Jordan dealing with the aspects of development and modernization of one of the administrative leaders in Jordan (the director of the Jordanian civil defense and his role in modernizing and calibrating the apparatus), and hopes to achieve the vision of His Majesty King Abdullah II Bin Al Hussein. The researcher said that the results of this study should be distributed to all administrative leaders to take advantage of the aspects, objectives, justifications, short term, medium term and long term strategic steps taken by the Jordanian Civil Defense Organization. King Abdullah II, to highlight the performance of the government, the largest achievement attest to the development of performance of the Jordanian civil defense..

\section{References}

1-ElBaradei, Laila (Contemporary Trends in the Study of Administrative Reform, Cairo, Journal of the Faculty of Economics and Political Science, Cairo University, number 20..

2-Al-Sabil Newspaper. Maj. Gen. Mustafa Al - Bazaeeh Visits Southern Civil Defense Training Center, Tuesday, 26 June, 2018.

3-Al-Haniti, Muhammad (1994), Trends of Directors towards Development and Administrative Reform in the Public Sector in Jordan - Amman: Yarmouk Research (Series of Human and Social Sciences), Vol. 10, No. 2, 1994..

4-Halwani, Ibtisam (1990), Change and its Role in Administrative Development, Journal of Public Administration, Riyadh: Institute of Public Administration, No. 67.

5-Strategic Plan for Civil Defense (2017 - 2019), Directorate General of Civil Defense, Hashemite Kingdom of Jordan, Amman... 
6-Abd ALbariDurra (1990); Assessment of Training Need Within the Context of Adminisstrative Reforms, International Journal of MANPOWER, Vol. 11, N7.

7-Al-Saeed, Khaled (2003), Obstacles to the Application of Technical Development in Security Systems and their Security Implications, Riyadh: Naif Arab Academy for Security Sciences (unpublished Master Thesis.(

,(2003)8- abed alharabheh(2003), The Effect of Administrative Development on the Performance of the Jordanian Accounting Bureau, Mu'tah, Mu'tah Magazine for Research and Studies, Volume (18), No.( 4.).

9-Al-Awamla, Nael (1992), Change and Organizational Development in Public Administration in Jordan, Yarmouk Research (Series of Human and Social Sciences), Volume (8), No. (2)..(

10- Al-Faouri, Rifaat, Al-Amari, Fatima (200), Trends of Managers of the Central Administration in the Service Sector Towards Development Administrative Development in the State of Qatar, Riyadh, King Saud University Journal of Science, vol(62)..

11- Al-Qariuti, Muhammad and Al-Anzi, Awad (2004), Administrative Development Efforts in Kuwait - An Evaluation Study in the Field, Riyadh: Journal of Public Administration Volume (44), No. (3

12- Jordanian Civil Defense Law No. 18 of 1999, General Directorate of Civil Defense, Hashemite Kingdom of Jordan, Amman..

13- Governorate, Ali (2016), National Education, Dar Jarir Publishing and Distribution, second edition..

14- Al-Nuaimi, Ahmad (1998), Management Development Strategies as an Approach to Organizational Development. An Applied Study on Abu Dhabi Municipality Department, Naif Arab University for Security Sciences.

General Directorate of Jordanian Civil Defense, website..15-

16- Al-Ghad newspaper of Jordan, an interview with Major General Mustafa al-Bazaiha, December 8, $2018 .$. 17-Jordanian News Agency, Civil Defense March, achievements and aspirations, 23/12/2018... 